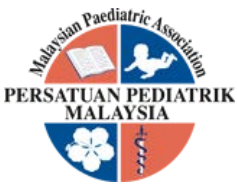

\title{
NEONATAL BUCCAL CELL COLLECTION: A NON-INVASIVE STRATEGY TO PROVIDE A RELIABLE SOURCE OF DNA FOR HIGH RESOLUTION MELTING ANALYSIS
}

\author{
Tian Pei Cheung ${ }^{1}$, Hans Van Rostenberghe', Narazah Mohd Yusoff' ${ }^{2}$, Noraida Ramli ${ }^{1}$, Nor \\ Rosidah Ibrahim ${ }^{1}$, Hisahide Nishio ${ }^{3}$, Surini Yusoff ${ }^{1,4}$
}

\begin{abstract}
Background: The low yield and quality of buccal-derived genomic DNA have reduced its applicability in various genetic research. The aim of this study was to assess the quantity, purity and genotyping efficiency of genomic DNA isolated from neonatal buccal swabs. Methods: Paired buccal swabs and whole blood samples were collected from 60 neonates with the mean age 5 days $(S D=1.57)$. The genomic DNA quantity and purity were measured by using Infinite ${ }^{\circledR} 200$ PRO NanoQuant reader and agarose gel electrophoresis. High-resolution melting (HRM) analysis was used to analyse the sequence variants present in uridine diphosphate glucuronosyltransferase $1 \mathrm{~A} 1$ (UGT1A1 c.211G $>\mathrm{A}$ ) and nuclear receptor subfamily 1, group I, member 3 (NR1/3 IVS8+116T>G) genes. Results: Buccal swabs provided lower mean genomic DNA concentration $(18.78 \pm 8.39 \mathrm{ng} / \mu \mathrm{l}$ versus $40.02 \pm 13.03 \mathrm{ng} / \mu \mathrm{l})$, yield $(2.63 \pm 1.17 \mu \mathrm{g}$ versus $8.00 \pm 2.61 \mu \mathrm{g})$. The purity of buccal samples however were inconsistent with 16 samples $(26.7 \%)$ having A260/280 ratios below 1.8 which indicated protein contamination. Genomic DNA purity for all blood samples were within the ideal range with average absorbance ratios of 1.8-2.0. However, all buccal genomic DNA demonstrated $100 \%$ genotype call rates for all variants. A complete genotype concordance was also observed between paired genomic DNA samples. Conclusion: Despite related to a reduced quantity and purity, neonatal buccal genomic DNA could generate reliable HRM genotyping results. Therefore, buccal swab collection is a promising alternative to the invasive blood sampling to provide genomic DNA for genetic analysis involving paediatric population.
\end{abstract}

\section{Keywords:}

Buccal, Non-invasive, High-Resolution Melting, Neonate, UGT1A1, NR113

\section{Introduction}

Sampling of genetic materials for molecular analysis is paramount in understanding the genetic basis of a disease as it determines the reliability of research findings and further affects the downstream clinical decisions. Epidemiologic studies, candidate gene analysis and genomewide association studies typically involve whole blood samples due to the critical demand for high-quantity and -quality DNA $[1,2,3]$. However, the collection of blood sample has disadvantages: a qualified practitioner is required to perform the venipuncture, risk of exposure to blood pathogens and expensive processing. Painful sensation and trauma from venipuncture could
Received: 19 March 2020; Accepted revised

manuscript: 25 April 2020

Published online: 27 April 2020 also reduce the participation rate and render the procedure unsuitable especially among paediatric population $[4,5]$.

As an alternative or supplement to blood sampling, the non-invasive approach of obtaining genetic materials from the buccal cells has overcame some potential drawbacks of the blood sampling $[6,7]$. Buccal cells can be collected from the mouth wash, saliva, swab and cytobrush to

${ }^{1}$ Department of Paediatrics, School of Medical Sciences, Universiti Sains Malaysia, Kelantan 16150, Malaysia.

${ }^{2}$ Advanced Medical and Dental Institute, Universiti Sains Malaysia, Pulau Pinang 11800, Malaysia.

${ }^{3}$ Department of Occupational Therapy, Faculty of Rehabilitation, Kobe Gakuin University, 518 Arise, Ikawadani-cho, Nishi-ku, Kobe, 651-2180 Japan.

${ }^{4}$ Human Genome Centre, School of Medical Sciences, Universiti

Sains Malaysia, Kelantan 16150, Malaysia.

Corresponding author: Surini Yusoff,

Department of Paediatrics, School of Medical Sciences,

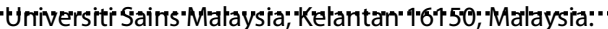


provide DNA for genetic analysis [8,9,10,11]. Although the sampling method of genomic isolation from buccal cells is cost-effective, uncomplicated and appropriate especially in paediatric setting, the DNA quantity and quality inconsistency have discredited the buccal cellsderived DNA isolation method [9].

The present study was undertaken to evaluate the total yield, purity and high-resolution melting (HRM) genotyping efficiency (genotype call and concordance rates) of neonatal buccal genomic DNA in comparison with that of the paired blood samples. To the best of our knowledge, there are no studies have compared the genotyping efficiency between buccal and blood DNA from paediatric population using HRM analysis.

\section{Methods}

\section{Subjects}

Our study subjects comprised of 60 neonates admitted to Hospital Universiti Sains Malaysia in the year 2014. The subjects constituted part of the genetic association study on neonatal hyperbilirubinaemia. All subjects were term neonates with gestational age $\geq 37$ weeks and birth weight $\geq 2500 \mathrm{~g}$. Informed consent was obtained from the parents of eligible neonates prior to collecting the samples. This study was approved by Human Research Ethics Committee of Universiti Sains Malaysia (No. USMKK/PPP/JEPeM [263.3(12)]).

\section{Genomic DNA isolation}

Two buccal swabs and whole blood samples were collected from each neonate during their first week of life. Buccal swabs were collected at least two hours after feeding. Sterile cotton swabs (Goodwood, China) were gently rubbed against the inside of both cheeks for about $20 \mathrm{~s}$ and kept in a 2-ml microcentrifuge tube. Whole blood samples $(200 \mu \mathrm{l})$ were obtained simultaneously with routine blood investigation and kept in a K2EDTA tube (Becton Dickinson, USA). Buccal and blood genomic DNA were isolated within three days by using ExegeneTM blood SV mini kit (GeneAll Biotechnology Co. Ltd., Korea) with some modifications in the protocols. For buccal genomic DNA extraction, $400 \mu \mathrm{L}$ of $1 \mathrm{X}$ PBS was added to the buccal swab. Proteinase $\mathrm{K}(20 \mu \mathrm{L})$ and $400 \mu \mathrm{L}$ of buffer $\mathrm{BL}$ were then added. For blood genomic DNA extraction, $20 \mu \mathrm{L}$ of proteinase $\mathrm{K}$ was added to $200 \mu \mathrm{L}$ of whole blood and $200 \mu \mathrm{L}$ of buffer BL was added subsequently. The mixture was then incubated at $56^{\circ} \mathrm{C}$ for $1 \mathrm{~h}$ (Thermomixer, Eppendorf Model 5436, USA) after vortexing and centrifugation steps. Then, the mixture was added with absolute ethanol (400 $\mu \mathrm{L}$ and $200 \mu \mathrm{L}$ for buccal and blood samples respectively). Transfer, centrifugation, discard and reinsert steps were repeated until all mixture had been applied to the SV column. For buccal samples, mixtures from two buccal swabs were combined in one SV column. The amount of buffers BW and TW used were $600 \mu \mathrm{L}$ and $700 \mu \mathrm{L}$ followed by centrifugation in every step. The amounts of elution buffer used to derive the buccal and blood genomic DNAs were $140 \mu$ and $200 \mu \mathrm{l}$ respectively. The isolated genomic DNA were stored at -20oC until HRM analysis.

\section{Assessment of DNA quantity and purity}

Genomic DNA concentration was determined spectrophotometrically by using Infinite ${ }^{\circledR} 200$ PRO NanoQuant reader (Tecan Group Ltd., Switzerland) which measured the absorbance at $260 \mathrm{~nm}$. The genomic DNA purity was provided by the ratio of absorbance at 260 and $280 \mathrm{~nm}$ (A260/A280). Absorbance ratios of 1.8-2.0 indicated good-quality genomic DNA [12]. The quality of buccal and blood genomic DNA was also evaluated via agarose gel electrophoresis using $1 \%$ agarose gel which was run at 80 Volt for $60 \mathrm{~min}$.

High-resolution melting and DNA sequencing analyses

HRM analysis of the uridine diphosphate glucuronosyltransferase 1A1 (UGT1A1 c.211G>A) and nuclear receptor subfamily 1, group I, member 3 (NR1/3 IVS8+116T >G) sequence variants were performed using buccal and blood genomic DNA $[13,14]$. The primer pairs were shown in Table 1. HRM assays were conducted on PikoReal 96 real-time PCR system (Thermo Fisher Scientific Inc., United States) using previously described protocols [15]. To assess the sensitivity, specificity and ability of buccal genomic DNA to provide reproducible HRM genotyping results, six paired buccal and blood genomic DNA samples were randomly selected for re-genotyping. Genotyping efficiency of the buccal genomic DNA was evaluated by comparing the genotype call and concordance rates of paired and duplicate samples. Random paired samples ( $\mathrm{n}=$ 20) were subjected to DNA sequencing analysis to validate the genotypes. 
Table 1. HRM primer pairs for genotyping UGT1A1 and NR1/3 variants

\begin{tabular}{llll}
\hline Sequence variants & $\begin{array}{l}\text { Primer sequence } \\
\left.\text { (5' to } \mathbf{3}^{\prime}\right)\end{array}$ & $\begin{array}{l}\text { Amplicon } \\
\text { size (bp) }\end{array}$ & $\begin{array}{l}\mathbf{T}_{\mathbf{a}} \\
\left({ }^{\circ} \mathbf{C}\right)\end{array}$ \\
\hline $\begin{array}{l}\text { UGT1A1 } \\
\text { rs4148323; c.211G }>A\end{array}$ & $\begin{array}{l}\text { F: GCAGCAGAGGGGACATGAAA } \\
\text { R: GCACAGGGTACGTCTTCAAG }\end{array}$ & 95 & 56 \\
$\begin{array}{l}\text { NR113 } \\
\text { rs4073054; IVS8+116T>G }\end{array}$ & $\begin{array}{l}\text { F: GGTGAAACATTGAGCTTGG } \\
\text { R: GCTGAAACGATGTGAGACAGG }\end{array}$ & 114 & 58 \\
\hline
\end{tabular}

$T_{a}$ annealing temperature; $F$ : forward; R: reverse.

\section{Results}

Quantity and purity of buccal and blood genomic DNA

Buccal genomic DNA was isolated from 60 neonates and compared with blood samples for the genomic DNA yield and quality, and HRM genotyping efficiency. Although wide ranges of genomic DNA concentration were obtained from both buccal and blood samples (Table 2), the mean buccal genomic DNA concentration (18.78 $\mathrm{ng} / \mu \mathrm{l})$ was lower than that of the blood samples $(40.02 \mathrm{ng} / \mathrm{\mu l})$. Buccal genomic DNA concentration of as low as $4.36 \mathrm{ng} / \mu \mathrm{l}$ was isolated while the minimum blood genomic DNA concentration was $15.38 \mathrm{ng} / \mathrm{\mu l}$. Meanwhile, the maximum amount of buccal genomic DNA concentration was 47.60 $\mathrm{ng} / \mu \mathrm{l}$ and $71.33 \mathrm{ng} / \mu \mathrm{l}$ was isolated from blood genomic DNA.

Table 2. Buccal and blood genomic DNA concentration and total yield

\begin{tabular}{lll}
\hline Genomic DNA extraction & \multicolumn{2}{l}{ Paired DNA samples $(\boldsymbol{n}=\mathbf{6 0}$ pairs $)$} \\
\cline { 2 - 3 } & Buccal swabs & Whole blood \\
\hline Genomic DNA concentration, $\mathrm{ng} / \mathrm{\mu l}$, mean $\pm \mathrm{SD}$ (range) & $18.78 \pm 8.39$ & $40.02 \pm 13.03$ \\
& $(4.36-47.60)$ & $(15.38-71.33)$ \\
Average elution volume, $\mu \mathrm{l}$ & 140 & 200 \\
Total DNA yield, $\mu \mathrm{g}$, mean $\pm \mathrm{SD}$ (range) & $2.63 \pm 1.17$ & $8.00 \pm 2.61$ \\
& $(0.61-6.66)$ & $(3.08-14.27)$ \\
\hline
\end{tabular}

For all blood samples, acceptable genomic DNA purity was obtained with average absorbance ratios within the ideal range of 1.8-2.0. However, buccal samples had inconsistent purity with 16 samples (26.7\%) having A260/280 ratios below 1.8 which suggested protein contamination of the buccal genomic DNA. Gel electrophoresis of some random buccal genomic DNA samples exhibited evidences of genomic DNA degradation by the presence of smeared genomic DNA bands (Supplementary 1). 


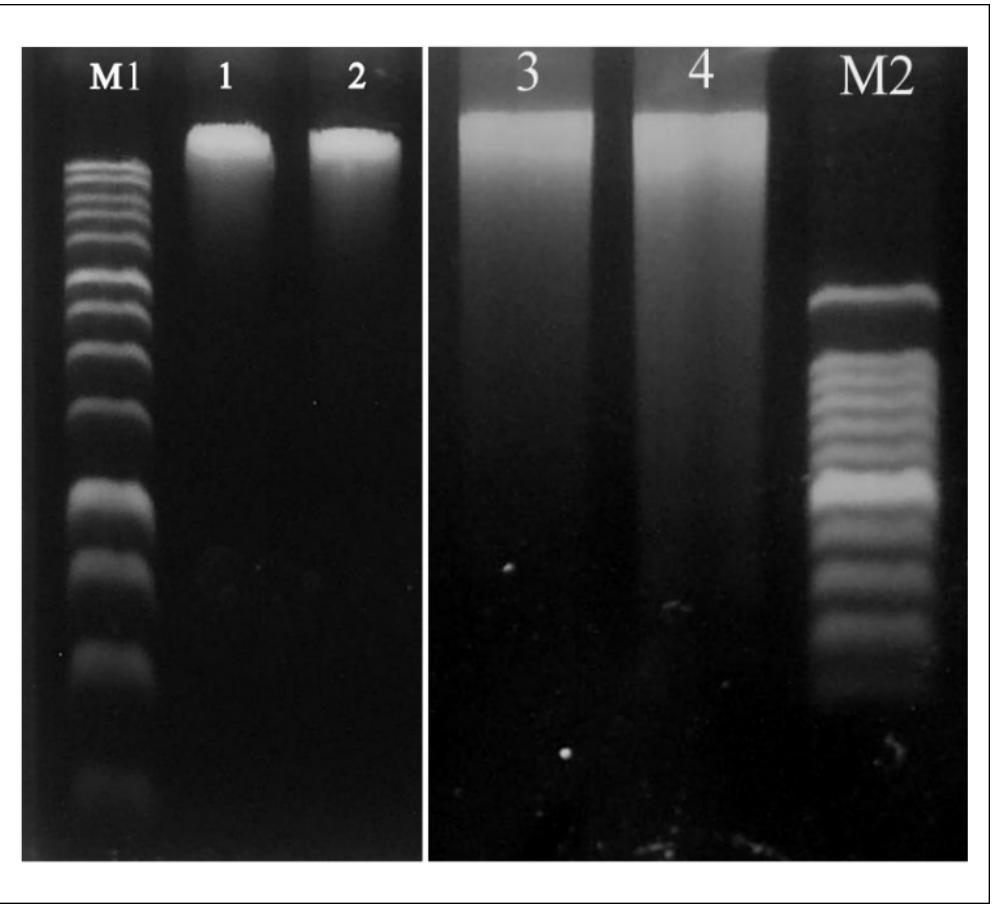

\section{Supplementary 1: Gel pictures of blood and buccal genomic DNA}

High-quality gDNA bands (lanes 1 and 2 ) of the blood samples were $>10 \mathrm{~kb}$ in size. Buccal gDNA exhibited evidences of DNA degradation by the presence of smeared bands and less intense bands of $>10 \mathrm{~kb}$ (lanes 3 and 4). Agarose gel electrophoresis (1\%) of gDNA were performed at $80 \mathrm{~V}$ for $60 \mathrm{~min}$. Lane $\mathrm{M} 1=1 \mathrm{~kb}$ DNA ladder; lane M2 = 100 bp DNA ladder; lanes 1 and $2=$ blood gDNA samples; lanes 3 and $4=$ buccal gDNA samples.

\section{Concordant HRM genotyping results between paired DNA}

High Resolution Melting analysis was successfully optimised. The quantification cycle $(\mathrm{Cq})$ values of both buccal and blood samples were in the range of 25-29 cycles although only $1 \mathrm{ng}$ of genomic DNA was used in each reaction. An optimal realtime PCR amplification graph suitable for HRM analysis is shown in Figure 1. HRM analysis of the sequence variants showed that all buccal and blood genomic DNA were successfully genotyped and achieved $100 \%$ genotype call rates. Buccal genomic DNA generated HRM genotyping results comparable with that of the blood samples. The melting patterns of wild type, heterozygous and homozygous variant genotypes were clearly distinguishable from each other, hence allowing straightforward determination of the genotypes (Figure 2). Besides, each genotype produced consistent and distinct melting patterns, thereby generating reproducible results that facilitated the genotype calling of unknown samples. 


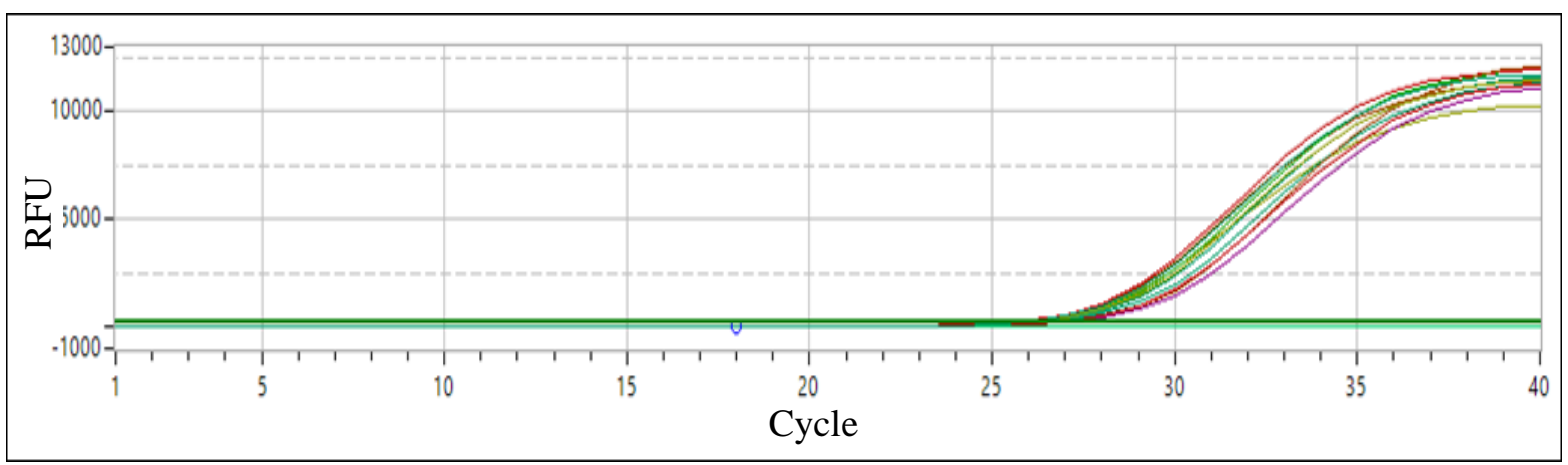

Figure 1. Real-time PCR amplification graph of c.211G >A using buccal DNA

Cq values (26-28 cycles) of buccal DNA samples were adequate to produce reliable HRM genotyping results. Samples amplified to the plateau phase following real-time PCR indicated that sufficient and comparable amounts of amplicons were available for the subsequent melting in HRM assays. The plateau phase also ensured that the HRM analysis would not be affected by variable amplicon amounts. RFU, relative fluorescence units.

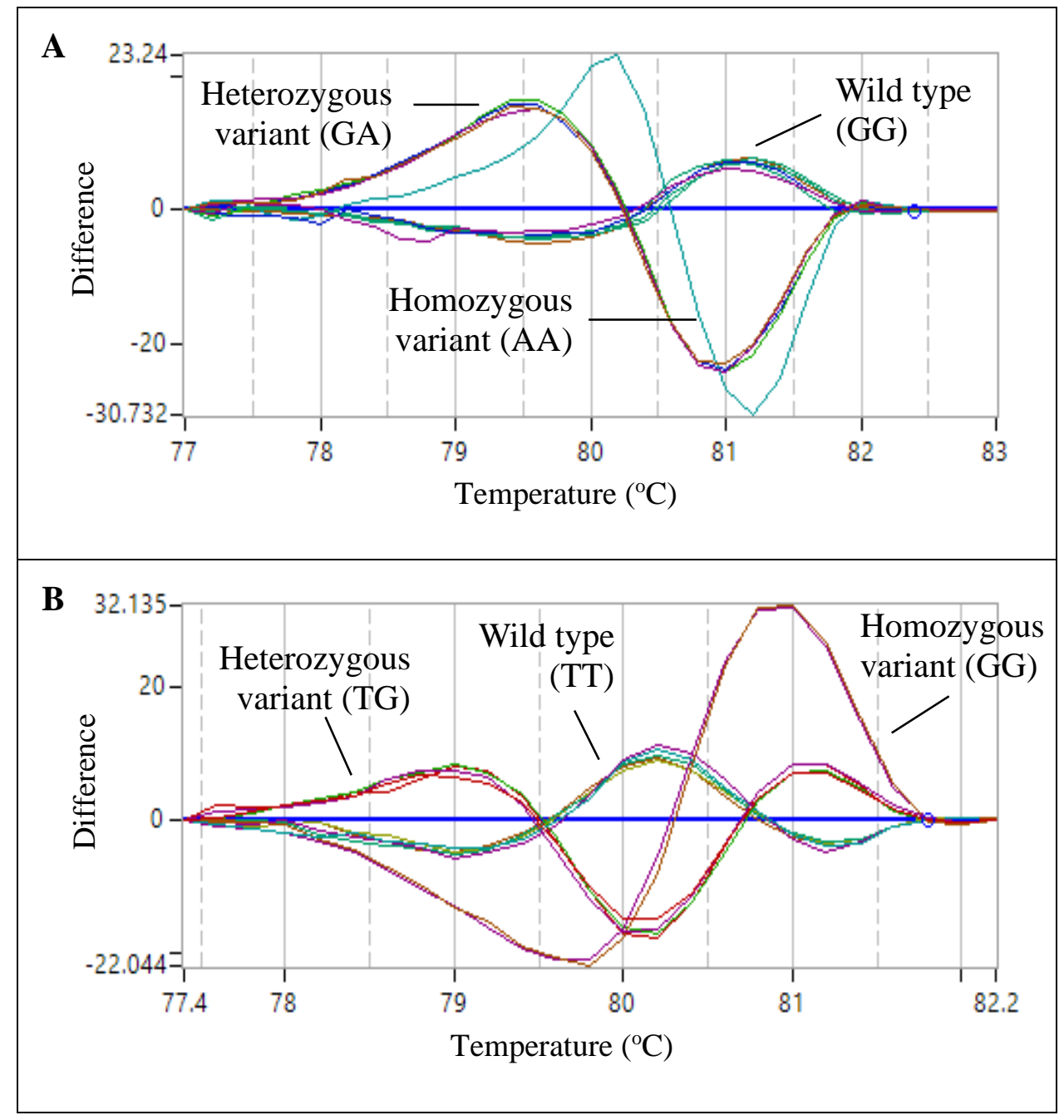

Figure 2. HRM analysis of UGT1A1 C.211G >A and NR1/3 IVS8+116T>G

HRM analysis demonstrated distinguishable melting patterns of wild type, heterozygous and homozygous variant genotypes of (A) c.211G $>A$ and (B) IVS8+116T>G using buccal DNA as template. The buccal DNA 
samples generated consistent melting patterns for each genotype. DNA sequencing analysis of random samples confirmed the genotypes.

The A260/280 ratios between DNA from buccal swab and blood samples were not significantly different thus the excellent concordance in genotyping (100\%) was achieved between genotypes and HRM melting patterns. Paired samples demonstrated the same genotypes for all variants that were evaluated. Table 3 shows the fully compatible HRM genotyping results between buccal and blood DNA samples. Besides, duplicate samples of paired buccal and blood DNA exhibited 100\% genotype call and concordance rates, indicating $100 \%$ sensitivity and specificity of the HRM analysis. Therefore, highly accurate and reproducible HRM genotyping results could be produced by the buccal DNA samples.

Table 3. Fully compatible buccal and blood HRM genotyping results

\begin{tabular}{lllll}
\hline & & \multicolumn{3}{l}{ Blood DNA ( $\boldsymbol{n}=\mathbf{6 0}$ pairs), $\boldsymbol{n}$} \\
\hline Buccal DNA & UGT1A1 c.211G $>$ A & GG & GA & AA \\
( $\boldsymbol{n}=\mathbf{6 0}$ pairs), $\boldsymbol{n}$ & GG & 56 & 0 & 0 \\
& GA & 0 & 3 & 0 \\
& AA & 0 & 0 & 1 \\
\cline { 2 - 5 } & NR1/3 IVS8+116T>G & $T$ & TG & GG \\
TT & 42 & 0 & 0 \\
& TG & 0 & 16 & 0 \\
GG & 0 & 0 & 2 \\
\hline
\end{tabular}

The frequencies ( $n$ ) of each genotype were shown for the paired buccal and blood DNA samples. There was no discrepancy between the buccal and blood genotyping results.

\section{Discussion}

DNA from buccal swab samples was significantly lower in concentration and yield but not quality. Our study has successfully demonstrated that the buccal genomic DNA samples generated satisfactory HRM genotyping results. Using buccal DNA, HRM assays of the UGT1A1 and NR1/3 sequence variants showed that the melting patterns of different genotypes were distinguishable from each other, thus facilitating genotype determination of all buccal samples. Besides, 100\% genotype call and concordance rates obtained with duplicate and paired buccal and blood samples indicated the accuracy and reproducibility of using buccal DNA in HRM analysis. Hence, our study suggests that the buccal swab could provide a reliable alternative source of DNA that is suitable for molecular genetic analysis.
A growing number of clinical and genetic studies utilising buccal DNA samples have been conducted. The successful use of buccal DNA has been documented in numerous applications including the short tandem repeat analysis, TaqMan assay, PCR-restriction fragment length polymorphism, whole exome sequencing and Illumina Beadchip arrays $[16,17,3]$. Similarly, the present study and our previous report which employed HRM analysis have demonstrated that the buccal DNA could generate clearly defined melting patterns for different genotypes of the variants [15]. In addition, comparable genotyping results between paired buccal- and blood-derived DNA implied that the buccal DNA could produce accurate genotype calls thereby confirming the reliability of applying buccal DNA in HRM analysis. 
Buccal cell collection is increasingly used as an alternative to blood sampling mainly due to its non-invasive, cost-effective, easy re-sampling and convenient system. Particularly, the collection method is suitable for paediatric population, healthy subjects and in case-control studies which require large number of participants where the request for blood drawing may reduce the participation rate [18]. Besides, additional blood drawing from neonates or children for research purposes is undesirable and the sampling procedure may result in pain or infection associated with venipuncture. Since the primary concern is on the care of subjects, the collection of buccal cells is thus more suitable for the susceptible group in comparison with blood sampling.

Despite the advantages of buccal cell collection, buccal DNA is commonly associated with some limitations. In this study, the DNA yield obtained from buccal swabs was lower than that of the whole blood samples. Likewise, several studies have also reported low DNA yields isolated from the buccal cells $[9,19]$. Besides, a wide range of buccal DNA yield was found in our study which could be due to the lag time between the sample collection and DNA isolation. To accommodate some applications requiring high yield of DNA, buccal DNA precipitation could be performed but the DNA samples might be exhausted rapidly. An interesting solution is by employing whole genome amplification (WGA). Notably, a study has revealed an improved buccal DNA yield with WGA while another study has uncovered that WGA could enhance the efficiency and validity of genotyping by using buccal DNA $[20,21]$. The collection of two buccal swabs in our study is estimated to provide DNA samples sufficient for at least 150 HRM reactions without the need for WGA.

Studies have suggested that there is potential for the contamination of neonatal buccal cells with breast milk from the mother $[22,23]$. Residual breast milk carrying small but quantifiable amount of maternal DNA may be obtained together during the collection of neonatal buccal cells [23]. However, such small amount of maternal DNA is insignificant in modulating the genotyping results which are mostly qualitative in nature [24]. The justification is consistent with our findings which found comparable genotyping results between paired buccal and blood DNA despite the possible contamination of neonatal buccal samples with maternal DNA from the breast milk. On the other hand, bacteria present in the oral cavity have been a significant element related to the buccal-derived genomic DNA considering the possible interference on the human buccal DNA quantity and quality [25]. However, amplification and HRM genotyping of our buccal samples were still achievable suggesting that the buccal samples contained adequate quantity of human DNA. Further, refrigeration of the buccal samples may be useful in restricting the growth of bacteria while reducing the degradation of human DNA [26].

There are several limitations in our study. We did not control the time of day during buccal cell collection and medications consumed by the mother. These factors may affect buccal DNA yield obtained from neonates and further studies are required to evaluate the relationship among these parameters. Nevertheless, the HRM genotyping results exhibited reliable detection of variants even by using a small amount of human DNA. However, future studies are still needed to evaluate the purity consistency of buccal DNA in a large cohort paediatric population.

\section{Conclusion}

Our approach of analysing buccal DNA through HRM analysis has demonstrated a simple, sensitive, rapid and an overall low-cost system. HRM analysis of paired buccal and blood DNA has exhibited comparable and accurate genotyping results. Hence, our study has successfully validated the use of buccal DNA as a promising alternative to blood and suitable for research involving paediatric population.

\section{Acknowledgments}

We greatly appreciate the support from the subjects' families and staff of neonatal ward and Human Genome Centre, Universiti Sains Malaysia 
in this project. This project was funded by APEX Delivering Excellence Grant 2012 (No.

\section{References}

[1] Rajatileka S, Luyt K, El-Bokle M, Williams M, Kemp $\mathrm{H}$, Molnar $\mathrm{E}$, et al. Isolation of human genomic DNA for genetic analysis from premature neonates: a comparison between newborn dried blood spots, whole blood and umbilical cord tissue. BMC Genetics. 2013; 14(1):105-13.

[2] Ooi DSQ, Tan VMH, Ong SG, Chan YH, Heng CK, Lee YS. Differences in AMY1 gene copy numbers derived from blood, buccal cells and saliva using quantitative and droplet digital PCR methods: Flagging the pitfall. Plos One. 2017 Jan 26; 1-13.

[3] van Dongen J, Ehli EA, Jansen $R$, van Beijsterveldt CEM, Willemsen G, Hottenga JJ et al. Genome-wide analysis of DNA methylation in buccal cells: a study of monozygotic twins and mQTLs. Epigenetics \& Chromatin. 2018; 11:54

[4] Dlugos DJ, Scattergood TM, Ferraro TN, Berrettinni WH, Buono RJ. Recruitment rates and fear of phlebotomy in pediatric patients in a genetic study of epilepsy. Epilepsy \& Behavior. 2005; 6(3):444-6.

[5] Hansen TvO, Simonsen MK, Nielsen FC, Hundrup YA. Collection of blood, saliva, and buccal cell samples in a pilot study on the Danish nurse cohort: comparison of the response rate and quality of genomic DNA. Cancer Epidemiology Biomarkers \& Prevention. 2007; 16(10):2072-6.

[6] Ghatak S, Muthukumaran RB, Nachimuthu SK. A simple method of genomic DNA extraction from human samples for PCR-RFLP analysis. Journal of Biomolecular Techniques. 2013; 24(4):224-31.

[7] Finnicum CT, Dolan CV, Willemsen G, Weber ZM, Petersen JL, Beck JJ, Codd V, Boomsma DI, Davies GE, Ehli1 EA. Relative telomere repeat mass in buccal and leukocyte-derived DNA. Plos One. 2017 Jan 26; 1-11.

[8] Küchler EC, Tannure PN, Falagan-Lotsch $P$, Lopes TS, Granjeiro JM, Amorim LMF. Buccal cells DNA extraction to obtain high quality
1002/PPSP/910342) of Universiti Sains Malaysia.

human genomic DNA suitable for polymorphism genotyping by PCR-RFLP and Real-Time PCR. J Appl Oral Sci. 2011; 467-71.

[9] Livy A, Lye S, Jagdish C, Hanis N, Sharmila V, Ler $L$, Pramod $B$. Evaluation of quality of DNA extracted from buccal swabs for microarray based genotyping. Indian Journal of Clinical Biochemistry. 2012; 27(1):28-33.

[10] Goode MR, Cheong SY, Li N, Ray WC, Bartlett CW. Collection and extraction of saliva DNA for next generation sequencing. Journal of Visualized Experiments. 2014; (90): e51697.

[11] Jenkins MM, Almli LM, Pangilinan F, Chong JX, Blue EE, Shapira SK et al. , Exome sequencing of family trios from the National Birth Defects Prevention Study: Tapping into a rich resource of genetic and environmental data. Birth Defects Res. 2019 December 01; 111(20): 1618-32.

[12] Gallagher SR, Desjardins PR. Quantitation of DNA and RNA with absorption and fluorescence spectroscopy. In, Current Protocols in Protein Science: John Wiley \& Sons, Inc. 2001.

[13] Yusoff S, Takeuchi A, Ashi C, Tsukada M, Ma'Amor $\mathrm{NH}$, Zilfalil BA, et al. A polymorphic mutation, c.-3279T>G, in the UGT1A1 promoter is a risk factor for neonatal jaundice in the Malay population. Pediatric Research. 2010; 67(4):401-6.

[14] Chew SC, Lim JSL, Singh O, Wong M, Lee EJD, Chowbay B. Genetic variations of NR1/3 and NR2B1 in Asian populations. Drug Metabolism and Pharmacokinetics. 2013; 28(2):169-76.

[15] Cheung TP, Van Rostenberghe $H$, Ismail $R$, Nawawi NN, Abdullah NA, Ramli N, et al. High resolution melting analysis of the NR1/3 genetic variants: Is there an association with neonatal hyperbilirubinemia? Gene. 2015; 573(2):198-204.

[16] Abraham J, Maranian M, Spiteri I, Russell R, Ingle $S$, Luccarini $C$, et al. Saliva samples are a viable alternative to blood samples as a source of DNA for high throughput 
genotyping. BMC Medical Genomics. 2012; 5(1):19-24.

[17] Said M, Cappiello C, Devaney JM, Podini D, Beres $A L$, Vukmanovic $S$, et al. Genomics in premature infants: a non-invasive strategy to obtain high-quality DNA. Scientific Reports. 2014; 4: 4286-9.

[18] Minucci A, Canu G, Concolino P, Guarino D, Boccia S, Ficarra S. DNA from buccal swab is suitable for rapid genotyping of angiotensinconverting enzyme insertion/deletion (I/D) polymorphism. Clinica Chimica Acta. 2014; 431(0):125-30.

[19] Poynter JN, Ross JA, Hooten AJ, Langer E, Blommer C,Spector LG.Predictors of mother and child DNA yields in buccal cell samples collected in pediatric cancer epidemiologic studies: a report from the Children's Oncology group. BMC Genetics. 2013;14:69.

[20] Zheng S, Ma X, Buffler PA, Smith MT, Wiencke JK. Whole genome amplification increases the efficiency and validity of buccal cell genotyping in pediatric populations. Cancer Epidemiology Biomarkers \& Prevention. 2001; 10(6):697-700.

[21] Beckett SM, Laughton SJ, Pozza LD, McCowage GB, Marshall G, Cohn RJ, et al. Buccal swabs and treated cards: methodological considerations for molecular epidemiologic studies examining pediatric populations. American Journal of Epidemiology. 2008;167(10):1260-7.

[22] Babovic-Vuksanovic D, Michels VV, Law ME, Lindor NM, Jalal SM. Maternal cell contamination of buccal smear samples in nursing neonates. Clinical Genetics. 1998;53(2): 114-18.

[23] Haas DM, Daum M, Skaar T, Philips S, Miracle $D$, Renbarger JL. Human breast milk as a source of DNA for amplification. The Journal of Clinical Pharmacology. 2011; 51(4):616-9.

[24] Lehmann AS, Haas DM, McCormick CL, Skaar TC, Renbarger JL. Collection of human genomic DNA from neonates: a comparison between umbilical cord blood and buccal swabs. American Journal of Obstetrics and Gynecology. 2011; 204(4): 362.e1-362.e6.

[25] Mahfuz I, Cheng W, White SJ. Identification of Streptococcus parasanguinis DNA contamination in human buccal DNA samples. BMC Research Notes. 2013; 6: 481-1.

[26] Nemoda Z, Horvat-Gordon M, Fortunato C, Beltzer E, Scholl J, Granger D. Assessing genetic polymorphisms using DNA extracted from cells present in saliva samples. BMC Medical Research Methodology. 2011; 11(1):170-82. 